\title{
Structural basis of cyclic nucleotide selectivity in cGMP dependent protein kinase II
}

\author{
James C. Campbell', Kevin Y. Li ${ }^{2}$, Jeong Joo Kim³ ${ }^{3}$, Gilbert Huang ${ }^{4}$, Albert S. Reger ${ }^{3}$, Shinya Matsuda ${ }^{5}$, \\ Banumathi Sankaran ${ }^{6}$, Todd M. Link ${ }^{7}$, Keizo Yuasa ${ }^{5}$, John E. Ladbury ${ }^{1,7}$, Choel Kim ${ }^{1,3,4^{*}}$ \\ From 7th International Conference on cGMP Generators, Effectors and Therapeutic Implications \\ Trier, Germany. 19-21 June 2015
}

\section{Background}

As a central mediator of the natriuretic peptide-cGMP signalling cascade, membrane bound type II cGMP dependent protein kinase (PKG II) is a key regulator of bone growth, renin secretion, and memory formation. It represents an important drug target for treating osteoporosis, cystic fibrosis, and memory loss [1-5]. In spite of its crucial physiological roles and its importance as a therapeutic target, little is known about its mechanisms of cyclic nucleotide selectivity and activation due to a lack of structural information. PKG II contains an Nterminal regulatory $(\mathrm{R})$-domain that binds a $\mathrm{C}$-terminal

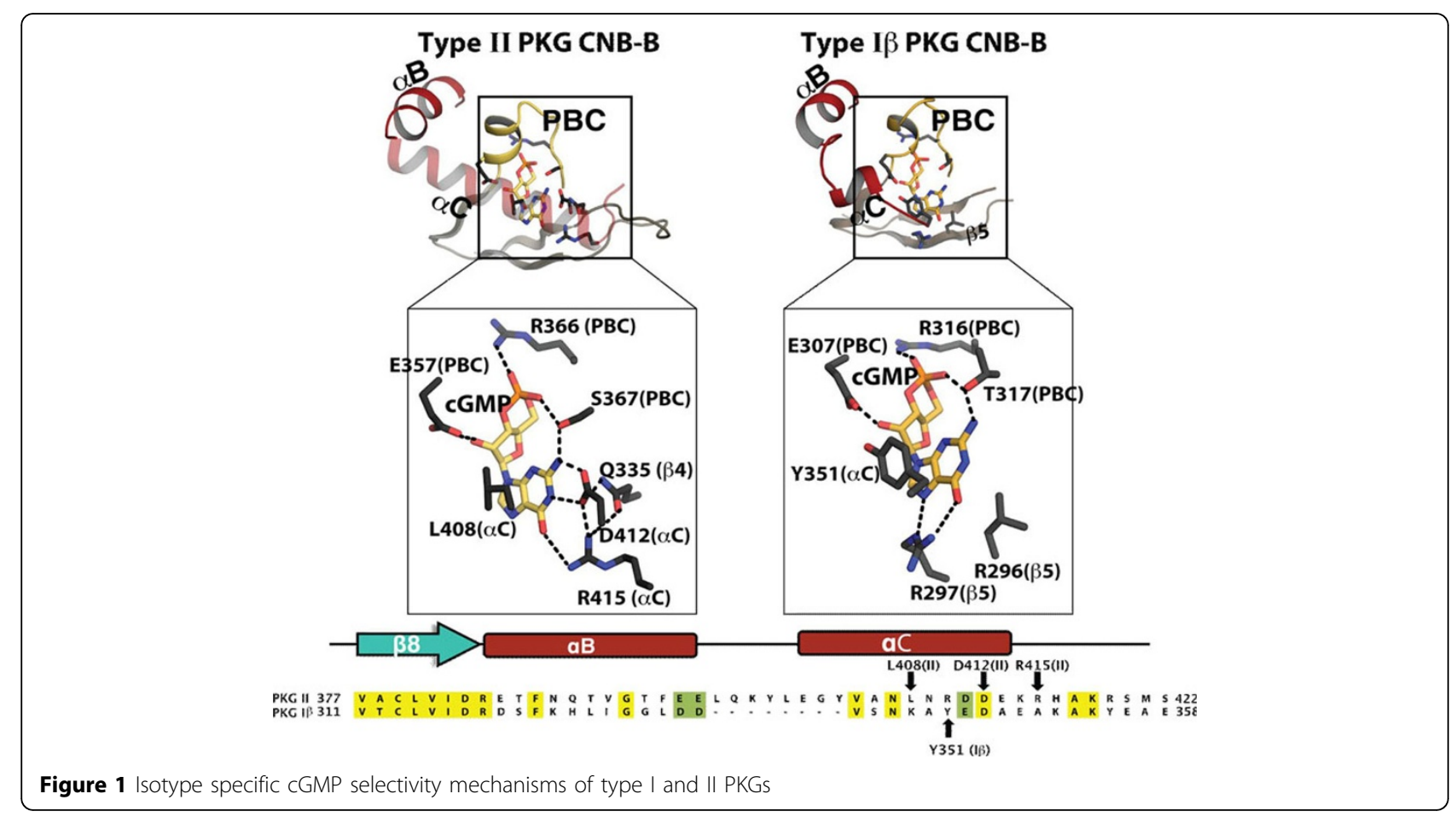

\footnotetext{
* Correspondence: ckim@bcm.edu

'Structural and Computational Biology and Molecular Biophysics Program,

Baylor College of Medicine, Houston, Texas, USA

Full list of author information is available at the end of the article
}

(0) 2015 Campbell et al. This is an Open Access article distributed under the terms of the Creative Commons Attribution License (http:// creativecommons.org/licenses/by/4.0), which permits unrestricted use, distribution, and reproduction in any medium, provided the original work is properly cited. The Creative Commons Public Domain Dedication waiver (http://creativecommons.org/publicdomain/ zero/1.0/) applies to the data made available in this article, unless otherwise stated. 
catalytic (C)-domain in the absence of cGMP. Binding of cGMP to the cyclic nucleotide binding domains (CNB-A and $\mathrm{B}$ ) within the $\mathrm{R}$-domain releases the $\mathrm{C}$-domain, leading to activation. We sought to understand the cyclic nucleotide selectivity and activation mechanisms of PKG II by studying each CNB domain.

\section{Methods and results}

We screened and identified CNB domains of PKG II that are suitable for our structural studies using a high throughput Ligation Independent Cloning method. Our affinity measurements of the resulting CNB domains showed that CNB-B binds cGMP with a higher affinity, providing almost 500 -fold selectivity, while CNB-A only offers 10 -fold selectivity [6]. To understand the structural basis of each domain's cGMP selectivity, we solved crystal structures of CNB-A and -B in the presence of cyclic nucleotides. The structures revealed that only CNB-B shows an ordered C-helix that shields the cGMP pocket and specifically interacts with the guanine moiety through several hydrogen bond and VWD contacts. In contrast, CNB-A displays an open pocket without a $\mathrm{C}$-terminal helix, resulting in fewer interactions with cGMP. Our mutation analysis demonstrated that the polar contacts at the C-helix of CNB-B are crucial for high cGMP selectivity and kinase activation.

\section{Conclusion}

Our structural comparison with cGMP selective PKG I CNB-B domain shows that it lacks cGMP specific hydrogen bonding contacts at the C-helix, which suggests a distinct cGMP selectivity mechanism for PKG II's CNB-B (Figure 1). Cyclic nucleotide compartmentalization is crucial for signalling specificity and exists in both cGMP and cAMP pathways [7-10]. Due to higher cAMP concentrations at the cell membrane compared to the cytosol, the higher cGMP selectivity seen in CNB-B of PKG II might be important in preventing activation of PKG II by cAMP, and this might minimize undesired cross-activation of both cyclic nucleotide signalling pathways.
References

1. Leier G, Bangel-Ruland N, Sobczak K, Knieper Y, Weber WM: Sildenafil acts as potentiator and corrector of CFTR but might be not suitable for the treatment of CF lung disease. Cellular physiology and biochemistry: international journal of experimental cellular physiology, biochemistry, and pharmacology 2012, 29:775-790.

2. Pfeifer A, Aszodi A, Seidler U, Ruth P, Hofmann F, Fassler R: Intestinal secretory defects and dwarfism in mice lacking cGMP-dependent protein kinase II. Science 1996, 274:2082-2086.

3. Rangaswami H, Marathe N, Zhuang S, Chen Y, Yeh JC, Frangos JA, Boss GR, Pilz RB: Type II cGMP-dependent protein kinase mediates osteoblast mechanotransduction. J Biol Chem 2009, 284:14796-14808.

4. Vaandrager $A B$, Hogema BM, de Jonge HR: Molecular properties and biological functions of cGMP-dependent protein kinase II. Frontiers in bioscience: a journal and virtual library 2005, 10:2150-2164.

5. Vaandrager $A B$, Smolenski A, Tilly BC, Houtsmuller AB, Ehlert EM, Bot AG, Edixhoven M, Boomaars WE, Lohmann SM, de Jonge HR: Membrane targeting of cGMP-dependent protein kinase is required for cystic fibrosis transmembrane conductance regulator $\mathrm{Cl}$ - channel activation. Proceedings of the National Academy of Sciences of the United States of America 1998, 95:1466-1471.

6. Huang GY, Kim JJ, Reger AS, Lorenz R, Moon EW, Zhao C, Casteel Darren E, Bertinetti D, VanSchouwen B, Selvaratnam R, Pflugrath JW, Sankaran B, Melacini G, Herberg FW, Kim C: Structural Basis for Cyclic-Nucleotide Selectivity and cGMP-Selective Activation of PKG I. Structure 2014, 22:116-124.

7. Castro LR, Schittl J, Fischmeister R: Feedback control through cGMPdependent protein kinase contributes to differential regulation and compartmentation of cGMP in rat cardiac myocytes. Circulation research 2010, 107:1232-1240.

8. Conti M, Mika D, Richter W: Cyclic AMP compartments and signaling specificity: role of cyclic nucleotide phosphodiesterases. The Journal of general physiology 2014, 143:29-38.

9. Neves SR, Tsokas P, Sarkar A, Grace EA, Rangamani P, Taubenfeld SM, Alberini CM, Schaff JC, Blitzer RD, Moraru II, lyengar R: Cell shape and negative links in regulatory motifs together control spatial information flow in signaling networks. Cell 2008, 133:666-680.

10. Wilson LS, Elbatarny HS, Crawley SW, Bennett BM, Maurice DH: Compartmentation and compartment-specific regulation of PDE5 by protein kinase G allows selective CGMP-mediated regulation of platelet functions. Proceedings of the National Academy of Sciences of the United States of America 2008, 105:13650-13655.

doi:10.1186/2050-6511-16-S1-A15

Cite this article as: Campbell et al: Structural basis of cyclic nucleotide selectivity in CGMP dependent protein kinase II. BMC Pharmacology and Toxicology 2015 16(Suppl 1):A15.

\begin{abstract}
Authors' details
'Structural and Computational Biology and Molecular Biophysics Program, Baylor College of Medicine, Houston, Texas, USA. ²Department of Biochemistry \& Cell Biology, Rice University, Houston, USA. ${ }^{3}$ Department of Pharmacology, Baylor College of Medicine, Houston, Texas, USA. ${ }^{4}$ Verna and Marrs McLean Department of Biochemistry and Molecular Biology, Baylor College of Medicine, Houston, Texas, USA. ${ }^{5}$ Department of Biological Science and Technology, The University of Tokushima Graduate School, Tokushima 770-8506, Japan. ${ }^{6}$ Berkeley Center for Structural Biology, Lawrence Berkeley National Laboratory, Berkeley, California, USA. ${ }^{7}$ Department of Biochemistry and Molecular Biology, The University of Texas MD Anderson Cancer Center, Houston, TX, USA.
\end{abstract}

Published: 2 September 2015

\section{Submit your next manuscript to BioMed Central and take full advantage of:}

- Convenient online submission

- Thorough peer review

- No space constraints or color figure charges

- Immediate publication on acceptance

- Inclusion in PubMed, CAS, Scopus and Google Scholar

- Research which is freely available for redistribution 